INTERNATIONAL MONETARY FUND

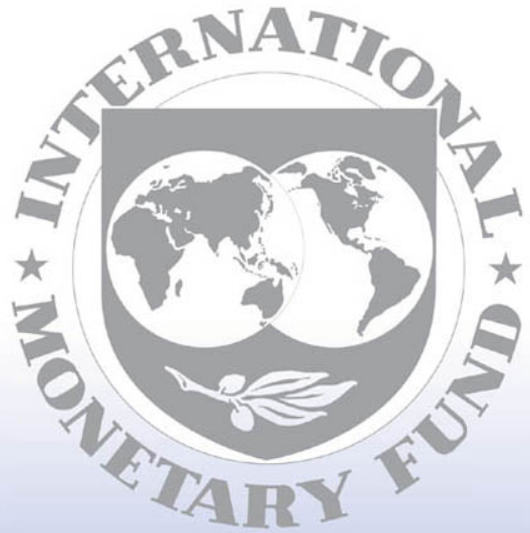

Staff

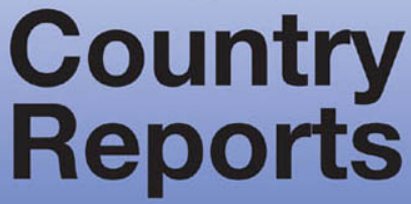




\section{Republic of Lithuania: Financial Sector Assessment Program Update- Technical Note-Basel Core Principles of Effective Banking Supervision Assessment}

This technical note on Basel Core Principles of effecting banking supervision assessment for the Republic of Lithuania was prepared by a staff team of the International Monetary Fund and the World Bank as background documentation for the periodic consultation with the member country. It is based on the information available at the time it was completed on April 2008. The views expressed in this document are those of the staff team and do not necessarily reflect the views of the government of the Republic of Lithuania or the Executive Board of the IMF.

The policy of publication of staff reports and other documents by the IMF allows for the deletion of market-sensitive information.

\footnotetext{
Copies of this report are available to the public from

International Monetary Fund • Publication Services

700 19th Street, N.W. • Washington, D.C. 20431

Telephone: (202) 623-7430 • Telefax: (202) 623-7201

E-mail: publications@imf.org • Internet: http://www.imf.org
}

Price: $\$ 18.00$ a copy

\section{International Monetary Fund Washington, D.C.}


This page intentionally left blank

CInternational Monetary Fund. Not for Redistribution 
FinANCIAL SECtOR Assessment PROGRAM UpdATE REPUBLIC OF LITHUANIA

BASEl Core Principles For EFFECTIVE BANKING

SUPERVISION ASSESSMENT

TECHNICAL NOTE

APRIL 2008

INTERNATIONAL MONETARY FUND

MONETARY AND CAPITAL MARKETS

DEPARTMENT
THE WORLD BANK Financial AND PRIVATE SECTOR DEVELOPMENT VICE PRESIDENCY Europe AND Central Asia Region Vice PRESIDENCY 


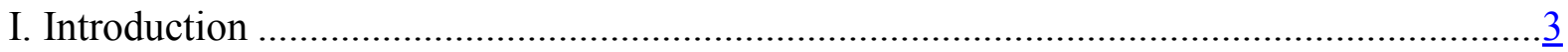

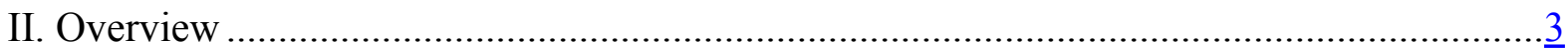

III. BCP Assessment ........................................................................................

Principle 1 -Objectives, independence, powers, transparency and cooperation ......... $\underline{5}$

Principles 2-5-Licensing and structure ....................................................... $\frac{5}{6}$

Principles $6-18$-Prudential regulation and requirements ....................................

Principles 19-21-Methods of ongoing banking supervision ................................ $\frac{9}{2}$

Principle 22-Accounting and disclosure..................................................

Principle 23 - Corrective and remedial powers of supervisors .............................11

Principles 24-25-Consolidated and cross-border banking supervision ....................12

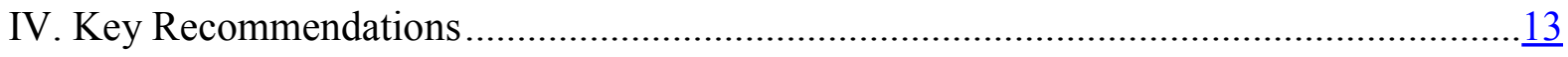

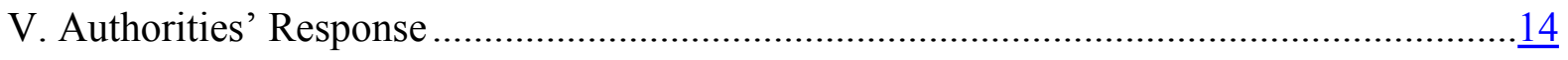

Tables

1. Recommended Action Plan to Improve Observance of Basle Core Principles ..................13

Appendixes

I. Key Recommendations from the 2002 Assessment-Basel Core Principles....................15 


\section{INTRODUCTION}

1. This note presents a targeted review and a follow up on the implementation of the recommendations of the 2002 assessment of Lithuania's compliance with the Basel Core Principles for Effective Banking Supervision (BCP) that was undertaken in the context of the original FSAP in 2002. ${ }^{1}$ The analysis does not constitute a full or formal reassessment of the initial BCP Assessment. The note was based on a self-assessment prepared by the Bank of Lithuania (BoL); interviews with staff of the BoL, industry, and professional associations; and various legal and other background documents. It follows the revised BCP, which was published by the Basel Committee in October 2006. A full-fledged verification of the implementation of all the Essential and Additional Criteria in the Methodology accompanying the revised BCP was not undertaken, and therefore no specific ratings (higher or lower than in the $2002 \mathrm{BCP}$ assessment) have been assigned for individual Core Principles.

\section{The BCP assessment carried out in Lithuania by the Financial Sector} Assessment Program (FSAP) report in 2002 found that banking supervision arrangements were of a high standard and either fully or largely complied with the Core Principles. On one Core Principle Lithuania was judged to be non-compliant at that time, which concerned the lack of explicit legal protection for BoL board members and supervisory staff. Besides providing for such protection, the main recommendations from the assessment concerned loan classification and provisioning, risk management systems and internal controls, public disclosure, and cooperation with foreign supervisory authorities. The 2002 recommendations are summarized in Appendix I.

3. This note is based solely on the laws, supervisory requirements, and practices that were in place at the time of the assessment. However, the mission made note of regulatory initiatives which have yet to be fully implemented or which are not final, such as the application of Basel II and the draft new Law on Anti-money laundering, combating the financing of terrorism (AML/CFT).

4. The mission is grateful to the BoL for its full cooperation and its assistance with the logistical arrangements and co-coordination of various meetings with industry bodies and companies. Discussions with BoL staff during a series of technical meetings and the self-assessment of compliance with the BCP that was provided facilitated a meaningful review of Lithuania's regime.

\section{OVERVIEW}

5. The Lithuanian financial system is centered around the banking sector and is dominated by three foreign-owned banks. The banking sector comprises nine banks-of which six are subsidiaries of foreign banks — and two branches of foreign banks. Foreign

\footnotetext{
${ }^{1}$ Prepared by Jan Rein Pruntel (formerly with De Nederlandsche Bank).
} 
entities account for around 93 percent of the sector's assets; Swedish banks together account for around 62 percent of the sector's assets. The three largest banks (SEB Vilniaus Bankas, Hansabankas, and DnB NORD Bankas) account for around 69 percent of banking sector assets and also have a substantial share of non-bank financial sector assets. The three banks generated three quarters of the 2006 credit growth. All three banks are owned by foreign banks with A+ Standard and Poor's credit ratings.

6. In the context of Lithuania's accession to the European Union (EU), laws and regulations affecting banking supervision have been changed to conform to $\mathbf{E U}$ Directives. As these Directives reflect the applicable Basel Committee papers, Lithuanian banking regulations are generally in line with international standards. Basel II regulations have been finalized and will become effective as of January 1, 2008, and a new draft law on AML/CFT has been presented to the Parliament and is expected to become effective as of the same date.

7. The BoL is responsible for supervising all banks in Lithuania, along with credit unions. It is headed by a Board which comprises its Governor, two Deputy Governors and two other Members. The Governor is appointed by Parliament on the recommendation of the President of Lithuania. The Deputy Governors and the other Members are appointed by the President on the recommendation of the Governor. The same procedures have to be followed for their dismissal prior to the expiration of their terms of office. Dismissal prior to the expiration of the term of office is only possible if they no longer fulfill the conditions required for the performance of their duties or if they have been found guilty of serious misconduct. The Law on the BoL explicitly provides that the Government and institutions of the State must respect the independence of the BoL and must not seek to influence it or its staff in the discharge of their duties.

\section{The BoL's Credit Institutions Supervision Department (CISD) comprises six} Divisions, with responsibility for licensing, on-site inspections, off-site monitoring, methodology and information, non-bank credit institutions, and international relations, respectively. Recently, the BoL also established a Financial Stability Department. The CISD employs about 65 persons, including specialists such as auditors, econometricians, operational risk experts and a real estate valuator.

9. The BoL has sufficient resources, including qualified staff. Its staff receive regular training to keep abreast of new developments. Market participants look favorably on the BoL staff's professionalism, citing as an example their cooperation with the banks in preparing for the Basel II Internal Risk-Based (IRB) approach, and say that the BoL staff is continuously improving itself. The BoL has significantly improved its collaboration with foreign supervisors. Memoranda of Understanding (MoUs) governing cooperation and information exchange have been concluded with the supervisory authorities of the countries where parent banks of Lithuanian banks are headquartered, the countries where Lithuanian banks operate subsidiaries or branches, as well as all the countries bordering on Lithuania. Cooperation with home country authorities has become very active since the application process for the Basel II 
IRB approach has started. The BoL is also party to the EU-wide multilateral MoU between ministries of finance, central banks and bank supervisory institutions, and it actively participates in various EU bodies on banking supervision.

\section{BCP ASSESSMENT}

10. The BoL has addressed most of the Recommended Actions to Improve Compliance with the Basel Core Principles for Effective Banking Supervision from the 2002 FSAP. The mission commends the BoL for the many important measures adopted since 2002. The measures that have been adopted are summarized below. Additional recommendations for consideration by the BoL are also noted. The discussion below is divided into the seven broad categories of the revised BCP.

Principle 1-Objectives, independence, powers, transparency and cooperation

11. As part of the preparations for adopting the euro, the Law on the BoL has been amended to reflect the Statutes of the European Central Bank (ECB). One of the results of this is that the BoL's independence has been further strengthened.

\section{Progress on recommended actions from the 2002 assessment}

12. Specific objectives of banking supervision have not been incorporated in the Law on the BoL. The authorities argue that this is not necessary since these objectives are already defined in the Law on Banks and as one of the tasks of the BoL in the Law on the Bank of Lithuania. Furthermore, they say that incorporating such objectives in the Law on the BoL would not be in conformity with the ECB's Statutes. However, the mission notes that the ECB's Statutes do not prohibit EU or euro zone central banks to have tasks that the ECB itself does not have, such as banking supervision.

13. The Law on the BoL has been amended to include a new Article 46(1) that provides explicit legal protection to BoL Board members and supervision staff. These persons are protected in carrying out their duties unless it is proven they undertook an illegal action with the intent to cause damage. This protection comes on top of the legal protection that is already provided for in the Civil Code. The Civil Code specifies that the legal person employing a natural person is responsible for the latter's actions while carrying out his duties in good faith.

\section{Principles 2-5-Licensing and structure}

14. There have been no major changes since the 2002 assessment with respect to banks' permissible activities, nor to the requirements with respect to ownership and the BoL's licensing regime. However, some changes have been made that reflect recommendations from the earlier assessment. 
15. The list of licensing criteria in the Law on Banks has been expanded to include all relevant matters that are subject to ongoing supervision. Article 9 of this Law now states that, when applying for a license, information also has to be supplied on matters such as risk management systems, internal controls, and the accounting organization. The minimum level of capital required for new banks has been maintained at 5 million euros in conformity with the EU Banking Directive. This amount strikes an appropriate balance between the objectives of having a contestable banking system and ensuring a reasonable degree of commitment by the founders of a bank.

16. The threshold for approval by the BoL of acquisitions of bank shares has been maintained at 10 percent of the bank's share capital, in conformity with the $\mathbf{E U}$ Banking Directive. However, a bank must notify the BoL of every case where 5 percent or more of the bank's authorized capital is acquired. The BoL has the right to appeal to the courts to request the forced sale of a bank's shares by a shareholder who fails to meet the fitness and propriety requirements set out in the Law on Banks and the Law on Financial Institutions or is exerting an influence which is detrimental to the sound management of the bank. Article 49 of the Law on Banks specifies limits on a bank's holdings of the capital of other legal persons.

\section{Principles 6-18-Prudential regulation and requirements}

17. Since the 2002 FSAP, the BoL issued new or revised regulations and letters addressing a number of prudential areas such as operational risk, large exposures, internal audit, loan accounting, public disclosure, anti money laundering, and capital. New regulations implementing Basel II will enter into force on January 1, 2008, and cover credit, market, and operational risk, capital adequacy, public disclosure and large exposures.

18. Following Lithuania's accession to the $\mathbf{E} \mathbf{U}$, the minimum capital adequacy ratio was reduced from 10 to 8 percent in 2005 in order to ensure a level playing field for Lithuanian banks in the European internal market. The effect of this measure on banks' capital requirements was partly mitigated by other recent measures by the BoL. These included a redefinition of residential mortgages, limiting eligible collateral to registered buildings the purpose of which is living and which are suitable for use, and a limitation on the inclusion of current year's profits in capital, which helps safeguard the quality of capital. Also, the BoL has strongly urged the banks to retain all profits made in 2005 and 2006, and intends to do so again with respect to profits made in 2007.

19. Stress tests on the banks' balance sheets and estimates of their economic capital indicate that existing cushions above the regulatory minimum capital requirement may not be sufficient to cover potential losses under severe circumstances. It is therefore important that the banks' capital base is strengthened further. The mission welcomes the fact that, where the Capital Requirements Directive (i.e., the EU transposition of Basel II) allows for national discretions, the BoL has chosen the more conservative option. For example, for 
commercial real estate loans the BoL has chosen to apply a 100-percent risk weight whereas a 50-percent risk weight would have been possible, and the maximum amount of a retail exposure has been set at 1 million litas (about 290,000 euros) instead of 1 million euros, limiting the amount of assets that receive a 75-percent risk weight.

\section{About 90 percent of residential mortgage loans is concluded at variable interest} rates (most commonly with 6 months intervals) and a substantial part is denominated in euros. This exposes the banks to an indirect credit risk since rising interest rates or a change in the euro exchange rate, however improbable, may cause debt servicing problems for unhedged borrowers. Additionally, while current loan-to-value ratios appear to be on the prudent side, these ratios already reflect the steep rises in real estate prices in recent years and therefore might reverse abruptly in the case of a significant slowdown. These risks are specific to Lithuanian banks and appear to be underestimated under the Basel I capital adequacy regime, and could also be underestimated under Basel II, both in the advanced and standardized approaches in Pillar 1. In view of the limited historical banking and macroeconomic time series in Lithuania, there is a significant risk that banks' IRB models would not capture the risk characteristics of the Lithuanian loan portfolios indicated above and therefore will underestimate regulatory capital needs. To the extent that these risks are not adequately covered under Pillar 1, they should be captured in Pillar 2 in the Basel II regime.

\section{Banks wishing to apply the IRB approach to calculate their capital requirements} will have to validate the applied internal rating systems and procedures, whereas those applying the advanced operational risk assessment approach will have to validate all the essential elements used. The BoL has issued Regulations on Validation and its Assessment that detail how the validation process will have to be performed. The BoL will carry out regular reviews of banks' validation processes. For Lithuanian banks with a foreign parent, the BoL's approval for using the IRB and AMA approaches is required, but the final decision rests with the home country supervisor. The BoL therefore closely cooperates with the home country supervisors in assessing these banks' models. It is expected that most Lithuanian banks will not be allowed to use IRB and AMA approaches before 2009. One Lithuanian bank is going to apply IRB and AMA approaches in 2008. This bank has performed test calculations of its capital requirements using the new approaches, which have been verified by the BoL. The BoL emphasized the preliminary character of these calculations and pointed out that a floor has been specified for the new capital requirement in the EU Directive.

22. The regulatory limit on open positions in euros has been abolished in 2004. While the BoL has correctly maintained the requirement that open euro positions have to be included in the calculation of required capital for foreign exchange risk, there seems to be some confusion among banks on this issue. Banks might have understood that the abolition of the euro position limit extends to capital adequacy calculations. While the mission is aware that the BoL does include capital charges on euro positions in banks' regulatory capital calculation, it found it somewhat unsettling that apparently not all banks are aware of the capital costs of carrying open euro positions. The BoL clarified this issue to the banks shortly after the conclusion of the FSAP mission. Furthermore, the mission acknowledges the 
position of the authorities regarding their full commitment to maintain the currency peg under the CBA and therefore not to re-impose restrictions on banks' net open positions in euro. The mission however encourages the BoL to continue to monitor closely risks arising from these exposures.

\section{Progress on recommended actions from the 2002 assessment}

\section{The authorities have considered specifying triggers for enforcement actions}

when a bank's capital falls below certain levels. However, they do not see merit in this given the small number of banks operating in Lithuania, which allows the BoL a thorough understanding of the risks and capital position of each of them. Banks' individual minimum capital requirements will continue to be kept under review by the Basel II Internal Capital Adequacy Assessment Process and the Supervisory Review and Evaluation Process, which should ensure that all banking risks, including the risk dynamics of the economy in general, will be captured. The BoL also considers that it has sufficient enforcement measures at its disposal to allow for an early resolution of any problems that may emerge at an individual bank. The mission accepts these arguments. The mission however recommends that, at a minimum, a balance sheet insolvency condition (zero net worth) should be included in the Law as a trigger for compulsory license withdrawal.

\section{In 2005 the BoL adopted a new regulation setting out the minimum} requirements for loan assessment and the formation of specific reserves. Under the new requirements, which implement IAS 39, specific reserves have to be calculated if there is objective evidence that a loan is impaired. The senior management of a bank is responsible for establishing the principles and procedures for assessing the impairment of loans, including procedures for the recognition of loss events and the calculation of the loss from the impairment. All significant loans and loans with respect to which objective evidence of impairment exists are to be subjected to an individual assessment. Loans which are not objectively impaired are grouped on the basis of similar risk characteristics and are subjected to a collective assessment. Under the old regulations, loans were classified into five risk groups which were each associated with a certain level of provisions. The BoL does not have exact data on how the new regulation, which should more accurately reflect the risk of individual loans, has affected the level of specific reserves. Following the 2006 Basel Committee guidelines on credit risk assessment and loan valuation, the BoL does not intend to set out additional requirements for loan loss provisioning beyond those in IAS 39 .

\section{A resolution adopted by the BoL in 2006 requires banks to publish information on the risks they have assumed and their risk management and internal control processes. These public disclosures are to be included in the annual report alongside the financial statements and should include implications for a bank's activities. The bank's board is held responsible for the accuracy and timeliness of the information made available to the public.}

26. The BoL revised the large exposure rules in 2004. Formerly, interbank loans with a maturity up to 30 days were excluded from the large exposure limit. This has been reduced to 
14 days, provided that these loans are not automatically rolled over. The large exposure rules also apply to intra-group lending, including lending to the parent bank. Article 53 of the Law on Banks requires that the terms and procedure for intra-group lending has to be approved by the bank's supervisory board, and that specific intra-group loans have to be approved by the bank's managing board. The Law on Banks also requires that the terms of lending to natural persons related to the bank may not be more favorable than the terms of lending to other clients.

27. The BoL regulations on internal control require that banks have an effective internal control system that ensures that all material risks are being recognized and continually assessed. The BoL has provided the banks with specific guidance on the management of operational risk and (separately) on information technology (IT) risk. The management bodies of a bank are held responsible by the BoL for the proper management of all material risks.

\section{The BoL's Resolution on Money Laundering Prevention Guidelines requires} banks to organize training for managers and staff members, including those (but not limited to) who directly deal with customers, with a view to ensuring proper implementation of measures for the prevention of money laundering. Anti money laundering measures have to be properly integrated into the bank's system of internal control. Bank managers are held responsible by the BoL for the implementation of adequate anti money laundering measures, including "know your customer" procedures. The government's Financial Crime Investigation Service is responsible for the coordination of anti money laundering measures and the measures taken against perpetrators. A new law on money laundering transposing the 2005 EU Directive on anti money laundering and countering the financing of terrorism is pending with the Parliament and is expected to come into force on 1 January 2008. This law will inter alia refine the procedures for cooperation among the institutions involved in preventing and detecting financial crime and will include measures to counter the financing of terrorism.

\section{Principles 19-21—Methods of ongoing banking supervision}

\section{The BoL conducts effective on-site and off-site supervision on all banks} operating in Lithuania. Regular reports are submitted by the banks to the BoL on balance sheets, capital adequacy, liquidity, concentrations both on the lending and on the funding side, loan impairment, as well as various other aspects. Also, the BoL has direct access to the management information systems of some of the larger banks. The information received is analyzed off-site and is used as input for the BoL's Early Warning System (EWS), which is based on a large number of financial ratios. If the EWS indicates that a particular bank is to be considered high risk, the BoL can require daily reports on the bank's liquidity position. Signals from the EWS may also lead to an increase in the bank's capital requirement, meetings of the BoL with the bank's management, or additional on-site inspections.

30. In normal circumstances, all banks are subject to a full-scope on-site inspection once a year (for small banks the scope may be limited to exclude irrelevant aspects, e.g., 
market risk other than foreign exchange risk if the bank has no significant trading portfolio). Additional inspections may be held, targeting on particular risk areas or addressing specific problems. The main focus of on-site inspections is on internal governance, including risk management and internal control systems. Credit files will be examined on a sample basis. Also, compliance with laws and regulations (including the new regulations that have been issued since the 2002 BCP Assessment) and the accuracy of supervisory reports are verified. On-site inspections result in a report which includes recommendations to address any shortcomings that may have been found. The recommendations are included in a timespecific action plan which is presented to the bank involved. The implementation of the action plan is monitored by off-site supervisors and is verified during the next on-site inspection.

\section{During on-site examinations the BoL assesses whether a bank's internal rules} and procedures for doubtful assets evaluation, classification and provisioning comply with the requirements. In case any shortcomings are found, the bank will be required to improve its loan assessment methodology. On-site inspectors also assess the quality of the loan portfolio and when necessary additional specific provisions may be required. Sanctions, including fines and removal of board members, may be imposed if a bank does not form sufficient provisions.

\section{The BoL is increasingly following a principle-based approach towards banking} regulation. This is an approach that has been endorsed by the Committee of European Banking Supervisors and that the mission supports. However, some banks indicated that they would welcome more guidance from the BoL on areas such as the Internal Capital Adequacy Assessment Process and stress testing. A balance needs to be struck, perhaps by differentiating the guidance that is given to individual banks according to their needs. This could be achieved by having more frequent contacts between the banks and on-site supervisors between annual inspections.

\section{There is scope for enhancing the interaction between the BoL's Financial}

Stability Department and the CISD. Interaction currently appears to be largely focused on the sharing of data on banks. However, in view of the fact that banking supervision is one of the tasks that the BoL has been entrusted with, the potential benefits of having the supervisory function within the central bank should be fully exploited. For example, the Financial Stability Department could usefully suggest macroeconomic stress scenarios that the Supervision Department could then apply to the banks. Also, the stress testing model developed by the Financial Stability Department could be used to help determine capital surcharges under the Pillar 2 supervisory review process.

\section{Principle 22-Accounting and disclosure}

34. The Law on Banks establishes that Lithuanian banks must keep their accounts and prepare reports according to the rules set by the BoL. Banks are required to publish quarterly and annual reports. The annual financial statements have to be checked by an audit 
firm. Audits have to be performed in accordance with the International Standards on Auditing. All Lithuanian banks are audited by large and internationally active auditing firms.

Progress on recommended actions from the 2002 assessment

35. A 2002 Resolution of the BoL on financial accounting prescribes that, in its accounting policies, each bank is required to establish accounting principles which are in line with the IAS/IFRS. The senior management of a bank is responsible for the correctness and accuracy of financial statements and their timely presentation. Accounting policies, procedures and the reliability of submitted supervisory reports are examined during on-site inspections. The BoL also monitors whether reports are submitted in due time and whether they are accurate.

36. The BoL has established requirements for publicly disclosed information in 2006 with a view to improving the transparency of activities of Lithuanian banks and enhancing the market discipline. The public is to be provided with timely, consistent and material information about the activities and financial condition of banks, the types of risk assumed, and the risk management mechanisms applied by a bank. The information provided must extend to any subsidiaries the bank may have. The key principle to be observed by banks when sharing information with the public is the materiality of information. Information about bank activities is to be regarded as material in disclosures if its omission, provision of insufficient detail or misstatement would result in wrong decisions by users. It would be useful if, in addition to present disclosure requirements, the banks were to issue simplified statements that are comprehensible and accessible to a wide public, for example by making them available at bank branches and on the internet.

\section{Principle 23-Corrective and remedial powers of supervisors}

37. The BoL has at its disposal a comprehensive range of supervisory tools to bring about timely corrective action. These range from the possibility to provide a bank with instructions on a particular course of action, to the application of sanctions. The sanctions listed in Article 72 of the Law on Banks include the possibility for the BoL to withdraw the license of a bank. The tools and sanctions are set out in a hierarchical order to ensure that they are proportionate to the severity of the situation to be remedied.

\section{Progress on recommended actions from the 2002 assessment}

\section{The Law on Banks has been amended to empower the BoL to levy fines on}

banks. The possible fines, which are listed in Article 74 of the Law, are proportionate to the seriousness of the offence and range from 0.1 percent to 2 percent of a bank's gross annual income. 


\section{Principles 24-25-Consolidated and cross-border banking supervision}

39. The Lithuanian authorities have systematically been enhancing cross-border cooperation and strengthening the financial crisis management framework. The policy of the BoL is to have written MoUs with all countries which have banking establishments in Lithuania and countries where Lithuanian banks are established, as well as all countries bordering on Lithuania.

40. Home country supervisors of the parent banks of Lithuanian banks apply the Lithuanian prudential requirements to the local subsidiaries in their consolidated supervision. For example, where Lithuanian capital requirements for particular assets (such as commercial mortgage loans) are higher than those in the home country, these higher requirements enter into the consolidated capital adequacy calculations. This practice ensures that the specific risks of the Lithuanian banking market are duly taken into account on a consolidated basis.

\section{Progress on recommended actions from the 2002 assessment}

41. The BoL has concluded bilateral MoUs with a number of foreign financial supervisory authorities including all that supervise parent banks of Lithuanian subsidiaries or branches. The BoL has also signed multilateral cross-border agreements including the EU-wide trilateral MoU of 2005 on crisis management cooperation. Most recently the BoL signed a MoU with the central banks of Estonia, Latvia, and Sweden on the management of a financial crisis in banks with cross-border subsidiaries or branches. Currently the BoL and the Swedish Financial Supervisory Authority are drafting a separate MoU on supervision of financial conglomerates as well as on the procedures of carrying out Supervisory Review and Evaluation Process (SREP).

42. The BoL is regularly provided by the home supervisor with information on the financial condition of parent banks of banks operating in Lithuania. The formal exchange of information is supplemented by frequent meetings with home country supervisors. Foreign-owned banks in Lithuania operate within exposure limits set by their parents. 


\section{KEY RECOMMENDATIONS}

Table 1. Recommended Action Plan to Improve Observance of Basle Core Principles

\begin{tabular}{|c|c|}
\hline 2006 Basel Core Principles (BCP) & Recommendations \\
\hline $\begin{array}{l}\text { Objectives, independence, powers, } \\
\text { transparency, and cooperation } \\
\text { BCP } 1\end{array}$ & $\begin{array}{l}\text { Consider incorporating the objectives of banking supervision } \\
\text { in the Law on the BoL on a basis consistent with the Law on } \\
\text { Banks. } \\
\text { Continue to advance the depth of staff expertise and skills. }\end{array}$ \\
\hline \multicolumn{2}{|l|}{$\begin{array}{l}\text { Licensing and structure } \\
\text { BCPs } 2-5\end{array}$} \\
\hline $\begin{array}{l}\text { Prudential regulation and requirements } \\
\text { BCPs } 6-18\end{array}$ & $\begin{array}{l}\text { Ensure that the credit risk ensuing from client borrowing at } \\
\text { variable interest rates or denominated in euros is fully } \\
\text { captured in Pillar } 1 \text { and/or Pillar } 2 \text {. } \\
\text { Clarify to banks that open positions in euros enter into the } \\
\text { capital adequacy calculations. } \\
\text { Closely monitor banks' open positions in euros. } \\
\text { Include, at a minimum, a balance sheet insolvency condition } \\
\text { (zero net wroth) in the Law as a trigger for compulsory } \\
\text { license withdrawal. }\end{array}$ \\
\hline $\begin{array}{l}\text { Methods of ongoing banking supervision } \\
\text { BCPs } 19-21\end{array}$ & $\begin{array}{l}\text { Consider giving more guidance to banks on an individual } \\
\text { basis, making use of more frequent contacts with on-site } \\
\text { supervisors. } \\
\text { Enhance the interaction between the Financial Stability } \\
\text { Department and the Credit Institutions Supervision } \\
\text { Department. }\end{array}$ \\
\hline $\begin{array}{l}\text { Accounting and disclosure } \\
\text { ВСР } 22\end{array}$ & $\begin{array}{l}\text { Encourage the banks to make public simplified information, } \\
\text { which should be comprehensible and accessible to a wide } \\
\text { public, alongside with the obligatorily disclosed information. }\end{array}$ \\
\hline \multicolumn{2}{|l|}{$\begin{array}{l}\text { Corrective and remedial powers of } \\
\text { supervisors } \\
\text { BCP } 23\end{array}$} \\
\hline $\begin{array}{l}\text { Consolidated and cross-border banking } \\
\text { supervision } \\
\text { BCPs } 24-25\end{array}$ & $\begin{array}{l}\text { Continue the close cooperation with the home country } \\
\text { supervisory authorities of Lithuanian banks with foreign } \\
\text { parents. }\end{array}$ \\
\hline
\end{tabular}




\section{AUTHORITIES' RESPONSE}

43. Following the FSAP Update mission in November 2007, the BoL has already acted upon some of the recommendations following from the BCP review and has provided comments on some of the others. The authorities noted that as from 2008, the BoL intends to assess each bank's additional capital needs under Pillar 2 and to establish additional capital requirements as needed. This will be done on the basis of the General Provisions for the Internal Capital Adequacy Assessment Process and the General Provisions for the Supervisory Review and Evaluation Process that the BoL has issued. This should result in capital surcharges for banks' individual risk not captured under Pillar 1. The banks are required to submit their first ICAAP report to the BoL at the end of the first quarter of 2008. In December 2007 the BoL has organized meetings with the banks to clarify that open euro positions are to be included in the capital adequacy calculation for market risks. All banks specified to the BoL at that time that they now include open euro positions in the calculations in the required manner.

44. With respect to the recommendation to strengthen the analytical cooperation between the BoL's Banking Supervision and Financial Stability Departments, the BoL notes that such cooperation is constantly increasing, for example when conducting banking sector stress testing. Moreover, the BoL has a cross-departmental committee that monitors national and international market developments, and it reassesses the cooperation needs between its departments every year.

45. The BoL points out that under the new loan assessment and classification methodology that was adopted in $\mathbf{2 0 0 5}$, losses regarding loan value reduction are accounted for only in case they are actually incurred. Differently from the previous methodology, losses that are expected due to future events are not accounted for even if they are very likely. This is in compliance with IFRS. The BoL believes that additional reporting in order to establish the effect of the change in methodology on the level of reserves would constitute an unjustified burden for the banks. As regards public disclosure by banks of simplified statements that are comprehensible and accessible to a wide public, the BoL points out that banks have some leeway to decide themselves what information should be publicly disclosed. 


\section{Appendix I. Key Recommendations from the 2002 Assessment-Basel Core Principles}

\begin{tabular}{|c|c|}
\hline $\begin{array}{l}\text { Reference } \\
\text { Principle }\end{array}$ & Recommended Action \\
\hline CP1 & $\begin{array}{l}\text { Incorporate specific banking supervision objectives in the Law on the BoL on a basis consistent } \\
\text { with the banking supervision objectives in the Law on Commercial Banks. } \\
\text { Make provision for the legal protection of members of the Board of the BoL and banking } \\
\text { supervision staff, while retaining robust accountability arrangements. } \\
\text { Strengthen the legal powers relating to the capacity to respond to bank failure events. }\end{array}$ \\
\hline CP3 & $\begin{array}{l}\text { Widen the statutory criteria for determining applications for a bank license to include all relevant } \\
\text { matters that are subject to ongoing supervision. } \\
\text { Keep the minimum capital requirement for a bank incorporated in Lithuania under periodic } \\
\text { review, to ensure that it strikes a reasonable balance between serving as a meaningful hurdle for } \\
\text { new bank entry and maintaining a contestable banking system. }\end{array}$ \\
\hline CP4 & $\begin{array}{l}\text { It may be desirable for the BoL to give further consideration as to whether the threshold for } \\
\text { approval—10 percent of a bank's share capital—is the appropriate level or whether a lower level } \\
\text { (possibly } 5 \text { percent) might be more appropriate, given the capacity of a } 5 \text { percent holding to give } \\
\text { the shareholder significant influence over a bank's Council and Board. It would also be desirable } \\
\text { if the BoL had the power to require a shareholder to sell all or part of their holding where that } \\
\text { holding was acquired without the BoL's approval or where the shareholders' circumstances have } \\
\text { changed since the approval was given, such that the bank's reputation or soundness could be } \\
\text { impeded by the shareholder in question retaining a significant interest in the bank. }\end{array}$ \\
\hline CP5 & $\begin{array}{l}\text { Strengthen the BoL's power to assess and approve a bank's acquisition of another financial } \\
\text { institution. }\end{array}$ \\
\hline CP6 & $\begin{array}{l}\text { Give consideration to specifying triggers for enforcement actions where a bank's capital ratio falls } \\
\text { below the required minimum level. } \\
\text { Keep the minimum capital ratio requirement under periodic review to ensure that the minimum } \\
\text { capital ratio for banks in Lithuania takes adequate account of banking system risks and the risk } \\
\text { dynamics of the economy in general. }\end{array}$ \\
\hline CP8 & $\begin{array}{l}\text { Keep the loan classification and provisioning rules under review, with a view to eventually } \\
\text { allowing banks to develop their own alternative loan classification and provisioning rules, subject } \\
\text { to BoL approval. } \\
\text { Strengthen the duties of bank directors to take responsibility for ensuring that their banks maintain } \\
\text { effective risk management systems and internal controls, including by requiring directors to issue } \\
\text { regular attestations of the extent of their satisfaction with the risk management systems and } \\
\text { internal controls and that the systems are being properly applied at all times. }\end{array}$ \\
\hline CP9 & $\begin{array}{l}\text { Give consideration to the feasibility and efficacy of reducing the maturity (currently of } 30 \text { days) } \\
\text { for inter-bank loans for the purpose of the large exposure limit, such that the limit applies to inter- } \\
\text { bank loans of a shorter maturity than } 30 \text { days. }\end{array}$ \\
\hline
\end{tabular}




\begin{tabular}{|c|c|}
\hline $\begin{array}{l}\text { Reference } \\
\text { Principle }\end{array}$ & Recommended Action \\
\hline CP10 & $\begin{array}{l}\text { Tighten the connected lending limit with respect to lending to parent banks or other corporate } \\
\text { shareholders and their affiliates and subsidiaries, so as to reduce the risk of intra-group contagion. } \\
\text { Give consideration to requiring banks to have a minimum number of fully independent, non- } \\
\text { executive directors. }\end{array}$ \\
\hline & $\begin{array}{l}\text { Give consideration to requiring bank directors to attest on a regular basis that the bank's connected } \\
\text { exposures have been subject to credit approval and review on terms at least equal to those } \\
\text { applicable to lending to non-connected parties, and make provision for appropriate penalties where } \\
\text { such statements are false or misleading. Give consideration to the merit of requiring directors to } \\
\text { attest that all connected exposures are in the commercial interests of the bank. }\end{array}$ \\
\hline CP12 & $\begin{array}{l}\text { The current } 25 \text { percent limit for aggregate net open currency positions should only be permitted } \\
\text { for those banks that, in the opinion of the CISD, have in place an adequate risk control } \\
\text { environment and have the necessary expertise in their trading department. Banks which lack one } \\
\text { of these the conditions should be subject to a lower limit. }\end{array}$ \\
\hline CP13 & $\begin{array}{l}\text { Give consideration to developing guidance for banks on a wider range of banking risks than is } \\
\text { currently the case (including payment system risks, business continuity risk, cyber risks, } \\
\text { reputation risks, etc). } \\
\text { Give consideration to requiring bank directors to make regular attestations stating whether they are } \\
\text { satisfied that their bank has adequate systems in place to identify, monitor and control all material } \\
\text { business risks and that those systems are being effectively applied at all times, and make provision } \\
\text { for appropriate penalties where such attestations are false or misleading. }\end{array}$ \\
\hline CP15 & $\begin{array}{l}\text { Provide examination staff with regular training to deepen their knowledge of the systems needed } \\
\text { to detect and prevent money laundering and other financial crimes. } \\
\text { Consider the efficacy of strengthening the duties of bank directors to satisfy themselves that their } \\
\text { banks have effective systems for detecting and, to the extent practicable, preventing money } \\
\text { laundering and financial crimes (including "know your customer" procedures) and that those } \\
\text { systems are being properly applied at all times. One option for achieving this could be to require } \\
\text { bank directors to sign regular attestations in respect of these matters and to hold them legally liable } \\
\text { for any attestations that are false or misleading. } \\
\text { Strengthen the coordination and cooperation between the agencies involved in detecting and } \\
\text { preventing money laundering and financial crimes, including by way of forums for regular } \\
\text { dialogue, exchange of views on policy issues, training and (where appropriate) coordination of on- } \\
\text { site examinations. }\end{array}$ \\
\hline CP20 & $\begin{array}{l}\text { Ensure that on-site examiners effectively assess the nature of risks, and the systems for managing } \\
\text { these risks, in the important subsidiaries of banks, and that there is a careful assessment of the } \\
\text { bank's systems for overseeing its subsidiaries. }\end{array}$ \\
\hline CP21 & $\begin{array}{l}\text { Minimize the extent to which banks are required to depart from IAS, and ensure that where any } \\
\text { such departures are being considered by the BoL, they are subject to thorough consultation with } \\
\text { banks, auditors and other affected parties. } \\
\text { Consider the efficacy of strengthening the public disclosure requirements for banks, including by }\end{array}$ \\
\hline
\end{tabular}




\begin{tabular}{|l|l|}
\hline $\begin{array}{l}\text { Reference } \\
\text { Principle }\end{array}$ & \multicolumn{1}{c|}{ Recommended Action } \\
\hline CP22 & $\begin{array}{l}\text { requiring banks to issue more frequent, comprehensive disclosures (e.g., six monthly or quarterly), } \\
\text { with disclosure of key prudential information (in addition to the standard financial information). } \\
\text { Consider requiring banks to issue simplified short form disclosure statements and to make these } \\
\text { available in bank branches and on the internet. Consider what actions the BoL itself can take to } \\
\text { promote wider public understanding of banks' disclosures, and to assist the financial news media } \\
\text { to provide well informed commentary and analysis of banks' disclosures. }\end{array}$ \\
\hline $\begin{array}{l}\text { Review the existing penalty provisions applicable to banks for non-compliance with supervisory } \\
\text { requirements, with a view to empowering the BoL (or the Courts on the application of the BoL) to } \\
\text { levy fines on banks, bank directors and bank CEOs, where the fines are proportionate to the } \\
\text { seriousness of the offence. }\end{array}$ \\
\hline $\begin{array}{l}\text { Consider the merit of modifying the existing statutory offence provisions and remedial/penalty } \\
\text { provisions in the law, so that they are set out as a hierarchy of measures covering different levels } \\
\text { of offence, and where the remedial and penalty provisions are specified in relation to each offence. }\end{array}$ \\
$\begin{array}{l}\text { Develop systems for maintaining a sound understanding of the financial condition of parent banks } \\
\text { (and other significant shareholders) of banks operating in Lithuania, for ensuring that the parent } \\
\text { banks are adequately supervising their operations in Lithuania, and for ensuring that the banking } \\
\text { operations in Lithuania have effective systems for keeping the parent banks well apprised of } \\
\text { developments of the local operations. } \\
\text { Complete MoUs with all parent bank supervisory authorities, and maintain a close dialogue with } \\
\text { them, including the regular exchange of information on banking groups operating in the respective } \\
\text { jurisdictions, on broader banking system developments in the respective countries, on relevant } \\
\text { policy issues and on methods for effectively coordinating the response to cross-border financial } \\
\text { distress or bank failure events. }\end{array}$ \\
\hline
\end{tabular}

